Atıf için / For Citation: A. Nadi Kaplan, C. Özel, "Perlit ve pomza agregalı polimer betonların radyasyon zırhlama performanslarının araştırılması", Süleyman Demirel Üniversitesi Fen Edebiyat Fakültesi Fen Dergisi, 16(1), 287-300, 2021.

\title{
Perlit ve Pomza Agregalı Polimer Betonların Radyasyon Zırhlama Performanslarının Araştırılması
}

\author{
Ali Nadi KAPLAN ${ }^{*}$, Cengiz ÖZEL ${ }^{1}$ \\ ${ }^{1}$ Isparta Uygulamalı Bilimler Üniversitesi, Teknoloji Fakültesi, Inşaat Mühendisliği Bölümü, 32260, \\ Isparta, Türkiye \\ *yazışılan yazar e-posta: nadikaplan@isparta.edu.tr
}

(Alınış / Received: 07.04.2021, Kabul / Accepted: 19.05.2021, Yayımlanma / Published: 27.05.2021)

\begin{abstract}
Özet: Polimer betonların inşaat mühendisliği uygulamalarında kullanımı yüksek mukavemetlerinin yanı sıra çevresel etkilere ve sıvı temasına karşı geçirimsizlik özelliklerinden dolayı her geçen gün artmaktadır. Bu kapsamda üretilen polimer betonların farklı amaçlar için de kullanılabilirlikleri büyük öneme sahiptir. Bu çalışmada, polyester reçine ile hacimce $\% 0$, $\% 15, \% 30$ ve $\% 45$ oranlarında perlit ve pomza agregalarının karıştırılmasıyla üretilen polimer betonların radyasyon zırhlama performansları deneysel ve teorik olarak araştırılmıştır. Polimer betonların gama radyasyonu etkisi altındaki radyasyon zırhlama özellikleri deneysel olarak ${ }^{60} \mathrm{Co}$ ve ${ }^{152} \mathrm{Eu}$ radyoaktif kaynakları kullanılarak, teorik olarak ise XCOM programı ile hesaplanmış, her bir polimer beton numunesi için radyasyon zayıflatma katsayıları belirlenmiştir. Son olarak yapılan deneysel çalışmadan ve teorik hesaplamadan elde edilen bulguların birbirleri ile ilişkileri karşılaştırmalı olarak ele alınmış ve elde edilen bulguların birbirleri ile uyum içerisinde olduğu ortaya çıkmıştır.
\end{abstract}

Anahtar kelimeler: Polimer beton, Agrega, Gama, Radyasyon zırhlama, Zayıflatma katsayısı, XCOM.

\section{Investigation of Radiation Shielding Performance of Perlite and Pumice Aggregate Polymer Concretes}

\begin{abstract}
The use of polymer concretes in civil engineering applications is increasing day by day due to their high strength as well as impermeability properties to environmental effects and liquid contact. In this context, it is very important that the polymer concretes produced can be used for different purposes. In this study, the radiation shielding performances of polymer concretes produced by mixing polyester resin with perlite and pumice aggregates in the ratio of $0 \%, 15 \%, 30 \%$ and $45 \%$ by volume were investigated experimentally and theoretically. Radiation shielding properties of polymer concretes under the effect of gamma radiation were calculated experimentally using ${ }^{60} \mathrm{Co}$ and ${ }^{152} \mathrm{Eu}$ radioactive sources and theoretically using XCOM program. Radiation attenuation coefficients were determined for each polymer concrete sample. Finally, the relationships of the findings obtained from the experimental study and the theoretical calculation with each other were considered comparatively and it was revealed that the obtained findings were in harmony with each other.
\end{abstract}

Key words: Polymer concrete, Aggregate, Gamma, Radiation shielding, Attenuation coefficient, XCOM. 


\section{Giriș}

Teknolojideki gelişmelerle birlikte radyasyon günlük yaşantımıza çeşitli şekillerde etki etmektedir. Tıpta, sanayide ve enerji üretiminde farklı amaçlar doğrultusunda kullanılan radyasyon çok geniş bir alana yayılmaktadır.

Radyasyon bir enerji olup, parçacık radyasyonu ve elektromanyetik radyasyon olarak ikiye ayrılmaktadır [1].

Elektromanyetik radyasyon; belirli bir enerjiye sahip ancak kütlesi olmayan radyasyon çeşididir. Bunlar, titreşim yaparak ilerleyen elektrik ve manyetik enerji dalgaları şeklindedir. Yayılmaları sırasında bulundukları ortamla etkileşime giren, hava ile teması halinde az da olsa enerji kaybına uğrayan elektromanyetik dalgalar, boşlukta sşık hızı ile yayılmaktadırlar. Ancak elektromanyetik radyasyonlar bir engele çarptıklarında, enerji transferi gerçekleşerek çarpışma sonrası oluşan ikinci dalga ile enerji farklılığ göstermektedirler. Aynı hız değerine sahip olan elektromanyetik dalgalar frekansları ile doğru ve dalga boyları ile ters orantılı olan enerji seviyelerine göre bir spektrum oluştururlar. Bunlara örnek olarak Gama ve X-Işınları gösterilmektedir. Spektrum içinde yer alan gama 1şınları, atomun çekirdeğinden kaynaklanan radyasyona örnek olarak gösterilirken, X-Işınları ise atomun yörüngelerinden kaynaklanan radyasyona örnek olarak gösterilmektedir [2].

X-Işınları çok yüksek elektromanyetik dalgalar halinde yayılır ve kimyasal bağları kırabilecek enerjiye sahiptirler. Bu enerji DNA'nın yapısını bozarak parçalayacak kadar büyük bir enerji taşımaktadır. Bunun neticesinde ise kanser gibi ölümcül hastalıklara neden olunmaktadir [3].

Gama 1şınları ise, atom çekirdeğinin kararlı hale gelmesi sırasında salınan elektromanyetik dalgalardır. Gama 1şınları tanecik değildir. Bunlar foton denilen kısa dalga boylu enerji demetleridir. Gama 1şınları enerjilerini iletene kadar boşlukta 1şık hızında epey yol alırlar ve ancak kurşun ve beton gibi özgül ağırlığı yüksek malzemelerle durdurulabilmektedirler [4].

Elektromanyetik radyasyonun soğurulması çeşitli olaylar sonucu gözlenmektedir. Fotonlar, içinden geçtikleri ortamın atomları ile etkileşime girerek soğurulabileceği gibi saçılmaya da uğrayabilmektedirler. Elektromanyetik radyasyonun madde ile etkileşimi çoğunlukla üç temel şekilde olmaktadır [2,5].

Bunlar; düşük foton enerjilerinde $(0-0,5 \mathrm{MeV})$ atomun yörünge elektronu ile etkileşimi sonrası ortaya çıkan fotoelektrik olay, atoma zayıf olarak bağlanmış bir dış yörünge elektronu veya serbest elektronun, enerjisi kendisine kıyasla çok daha büyük olan bir fotonla $(0,5-1 \mathrm{MeV})$ çarpışması sonucunda meydana gelen etkileşim olan Compton saçılımı ve yüksek enerjili bir fotonun atom çekirdeği içerisindeki yüksek elektromanyetik alan ile etkileşime girerek yok olması ve bir elektron-pozitron çifti oluşturması ile gerçekleşen çift oluşumu olayıdır [2,5-8].

$\mathrm{Bu}$ olayların ortaya çıkma ihtimali $\mathrm{X}$ ve gama ışınlarının foton enerjisine ve etkileştiği maddenin atom numarasına bağlı olarak değişmektedir $[6,8]$. 
Tüm bu anlatılanların ışı ğında günümüzde insanlar radyasyon ile doğrudan veya dolaylı bir şekilde temas halinde bulunmaktadır. Bu etkileşim sonucunda ise toplumda ve tüm canlı organizmalarda sağlık açısından risk oluşabilmektedir.

Canlılarda radyasyondan kaynaklı oluşması muhtemel riskleri ortadan kaldırmak için radyasyondan korunma kavramı ortaya çıkmıştır. Radyasyonun zararlı etkilerinden korunmanın üç temel kuralı; zaman, mesafe ve zırhlama olarak belirtilmektedir [9].

Zaman kuralını ele alacak olursak; radyasyon ortamında ne kadar az zaman geçirilirse o kadar az doza maruz kalınmakta, geçirilen zaman ne kadar çok artarsa alınan doz o kadar artmaktadır. Dolayısıyla radyasyona maruz kalan maddenin soğurduğu doz miktarının zamanla doğru orantılı olarak değiştiği ortaya çıkmaktadır [2].

Mesafe kuralında ise; radyasyon kaynağından uzaklaştıkça radyasyonun şiddeti, kaynağa olan uzaklığın karesi ile ters orantılı olarak azalmaktadır. Yani radyasyon kaynağından ne kadar çok mesafeli olunursa maruz kalınabilecek doz miktarı o ölçüde azalacaktır [10].

Radyasyon zırhlaması kavramı ise radyasyonun beklenmedik etkilerinden korunmak için hayati bir öneme sahiptir. Radyasyon zırhı en basit şekilde radyasyon kaynağı ile canlı arasına konulan ve radyasyonun etkilerinin canlılara ulaşmasını mümkün olduğunca engellemesi gereken malzemelerdir.

Yüksek radyasyon zayıflatma performansına sahip malzemelerin hazırlanması, radyasyondan korunma uygulamalarındaki en önemli konulardan biridir [11]. Radyasyon zırhlaması çeşitli malzemelerle yapılmaktadır. Zırhlama bakımından en etkili malzemeler yüksek atom numaralı ve özgül ağırlığı büyük olan elemanlardan yapılmış malzemelerdir. En genel kullanılan malzemeler kurşun ve betondur. Betonların özgül ağırlıkları arttırılarak radyasyon kalkanı olarak kullanılması daha elverişli hale gelmektedir. $\mathrm{Bu}$ amaçla genel olarak radyasyona maruz kalınan yerlerde ağır beton denilen yüksek birim ağırlıklı agregalar ile üretilen yüksek yoğunluklu betonların kullanımı ile radyasyon zırhlama özellikleri iyileştirilebilmektedir. Beton; nükleer santrallerde, tıbbi birimlerde ve radyoaktif sızdırmazlığın gerekli olduğu yapılarda, ekonomik olması, üstün zırhlama performansları, düşük bakım ve üretim kolaylıkları nedeniyle radyasyon koruyucu malzeme olarak yaygın bir şekilde kullanılmaktadır $[3,8,12-14]$.

Bir beton çeşidi olan polimer betonlar ise, beton üretiminde kullanılan çimento bağlayıcısının tümü veya bir kısmı yerine polimerlerin kullanılması ile elde edilir [15].

Polimer Beton (PC), Portland çimento betonuna kıyasla yüksek sıkışma mukavemeti, geliştirilmiş dayanıklılık özellikleri, yüksek süneklik, agresif kimyasallara direnç ve üstün sağlamlık derecesi ile çelik ve beton yüzeyler için inşaat ve onarım çalışmalarında yaygın olarak kullanılan bir malzemedir [16].

Ayrıca polimer betonlar ile sadece birkaç saat içinde çok yüksek (140 MPa) basınç dayanımlarına ulaşılmasına olanak sağlanmıştır [17].

Polimer betonlar; agrega ve/veya fiber içeren faz malzemeleri ile faz malzemeleri bir arada tutan, yükü faz malzemelere ileten ve faz malzemeleri çevresel etkilerden koruyan bağlayıcı matris malzemelerin fiziksel olarak bir araya gelmesinden oluşmaktadır [18]. 


\section{Materyal ve Metot}

$\mathrm{Bu}$ çalışma kapsamında matris malzeme olarak polyester reçine, faz malzeme olarak çeşitli oranlarda perlit ve pomza agregalarının kullanıldığı polimer beton kompozitleri üretilmiştir. Çalışmada kullanılan matris malzeme sıvı formda olup, faz malzemeler ise en büyük tane boyutu $150 \mu \mathrm{m}$ (mikron) olacak şekilde granül halde sabit tane büyüklüğünde seçilmiştir.

Üretilen polimer beton numunelerinin radyasyon zırhlama performansları deneysel ve teorik olarak araştırılmıştır.

\subsection{Malzemeler ve özellikleri}

\subsubsection{Polyester reçine}

Polimer betonların üretiminde bağlayıcı polimer malzeme olarak kullanılan polyester reçine Poliya firmasından temin edilen Polipol 314-DT alev ilerletmeyen dolgu tipi polyester reçinedir. Polyester reçine seçilmesindeki temel sebep yüksek kimyasal ve mekanik dayanımlarının yan ısıra gıda temasına da uygun olduğu için insan sağlığına olumsuz etkide bulunmamalarıdır.

\subsubsection{Perlit}

Perlit, elverişli bir sıcaklığa kadar 1sıtıldığında genleşen ve gözenekli bir hale gelen volkanik menşeili ve doğal olarak oluşan asidik bir camdır. Çalışmada kullanılan perlit agregası Pomza Export Madencilik San. ve Tic. A.Ş. İzmir ili Menderes ilçesi fabrikasından temin edilmiştir. Perlit agregasının teknik özellikleri de aynı fabrikadan temin edilmiş olup Tablo 1'de gösterilmiştir.

Tablo 1. Perlit agregasının teknik özellikleri

\begin{tabular}{c|cccccccc}
\hline Bileşen & $\mathrm{SiO}_{2}$ & $\mathrm{Al}_{2} \mathrm{O}_{3}$ & $\mathrm{Fe}_{2} \mathrm{O}_{3}$ & $\mathbf{M g O}$ & $\mathrm{Na}_{2} \mathrm{O}$ & $\mathrm{K}_{2} \mathrm{O}$ & $\mathbf{C a O}$ & $\mathrm{TiO}_{2}$ \\
\hline $\begin{array}{c}\text { Ăgırlıkça } \\
\text { Yüzzde }\end{array}$ & 73 & 14 & 0,98 & 0,13 & 3,45 & 4,5 & 0,35 & 0,12 \\
\hline
\end{tabular}

\subsubsection{Pomza}

Isparta pomza yatakları olarak zengin bir ilimizdir. Türkiye bilinen pomza rezervinin yaklaşık \%2'sine sahiptir. Çalışmada kullanılan pomza agregası Isparta Belediyesi Bims Yapı Elemanları San. ve Tic. A.Ş. (ISBAŞ) bünyesinde bulunan ISBAŞ Bimsblok Fabrikası'ndan temin edilmiştir. Çalışmada kullanılan pomza agregasının teknik özellikleri ISBAŞ Bimsblok Fabrikası'ndan temin edilmiş ve Tablo 2'de gösterilmiştir.

Tablo 2. Pomza agregasının teknik özellikleri

\begin{tabular}{c|cccccccc}
\hline Bileşen & $\mathrm{SiO}_{2}$ & $\mathrm{Al}_{2} \mathrm{O}_{3}$ & $\mathbf{F e}_{2} \mathrm{O}_{3}$ & $\mathbf{M g O}$ & $\mathrm{Na}_{2} \mathrm{O}$ & $\mathbf{K}_{2} \mathrm{O}$ & $\mathbf{C a O}$ & $\mathbf{T i O}_{2}$ \\
\hline $\begin{array}{c}\text { Ăgırlıkça } \\
\text { Yüzde }\end{array}$ & 58,88 & 18,74 & 5,93 & 2,95 & 4,25 & 3,66 & 2,16 & 0,45 \\
\hline
\end{tabular}




\subsection{Uygulanan testler ve kullanılan cihazlar}

\subsubsection{Polimer betonların yoğunluklarının belirlenmesi}

Polimer betonların deneysel yoğunluklarını belirlemek için Isparta Uygulamalı Bilimler Üniversitesi, İnşaat Mühendisliği Bölümü, Yap1 Malzemeleri Laboratuvarı'nda deneysel çalışmalar gerçekleştirilmiştir. Deneysel çalışma kapsamında üretilen her karışımdaki numunelerin kuru ağılık, suya doygun ağırlık ve Arşimet terazisi ile su altındaki ağırlıkları hesaplanmıştır.

Hesaplamalarda kullanılan denklem [19] aşağıda gösterilmiştir.

$$
\rho_{p c}=\rho_{w} \frac{M_{0}}{M_{1}-M_{2}}
$$

Burada;

$\rho_{\text {pc: }}$ Polimer betonların deneysel yoğunluğu

$\rho_{\mathrm{w}}$ : Suyun ölçüm sicaklığındaki yoğunluğu

$\mathrm{M}_{0}$ : Numunenin kuru ağırlığ1

$\mathrm{M}_{1}$ : Numunenin suya doygun ağırlı̆̆

$\mathrm{M}_{2}$ : Numunenin su altındaki ağırlığı (Arşimet terazisi ile ölçülen)

\subsubsection{Radyasyon zırhlamasi deneyi}

Radyasyon zırhlaması deneyleri Samsun Ondokuz Mayıs Üniversitesi Fen-Edebiyat Fakültesi Fizik Bölümü bünyesinde bulunan Nükleer Fizik Laboratuvarı'nda gerçekleştirilmiştir. Deneylerde kullanılmak üzere her polimer beton serisi için $40 \times 40 \times 10 \mathrm{~mm}$ boyutlarında numuneler üretilmiştir. Deneysel çalışmada ${ }^{60} \mathrm{Co}$ ve ${ }^{152} \mathrm{Eu}$ radyoaktif kaynaklarının NaI(TI) dedektörü üzerine yerleştirilmesi için özel olarak tasarlanmış bir deneysel düzenek ile birlikte gama spektrum analizi yapan bilgisayar kullanılmıştır. Deney düzeneği ve şeması Şekil 1 ve Şekil 2'de gösterilmiştir. Ayrıca deneysel hesaplamalarla karşılaştırmak için web tabanlı bir veri tabanı olan XCOM programı (XCOM: Photon Cross Sections Database) kullanılarak her polimer beton serisi için teorik hesaplamalar da yapılmıştır [20]. 


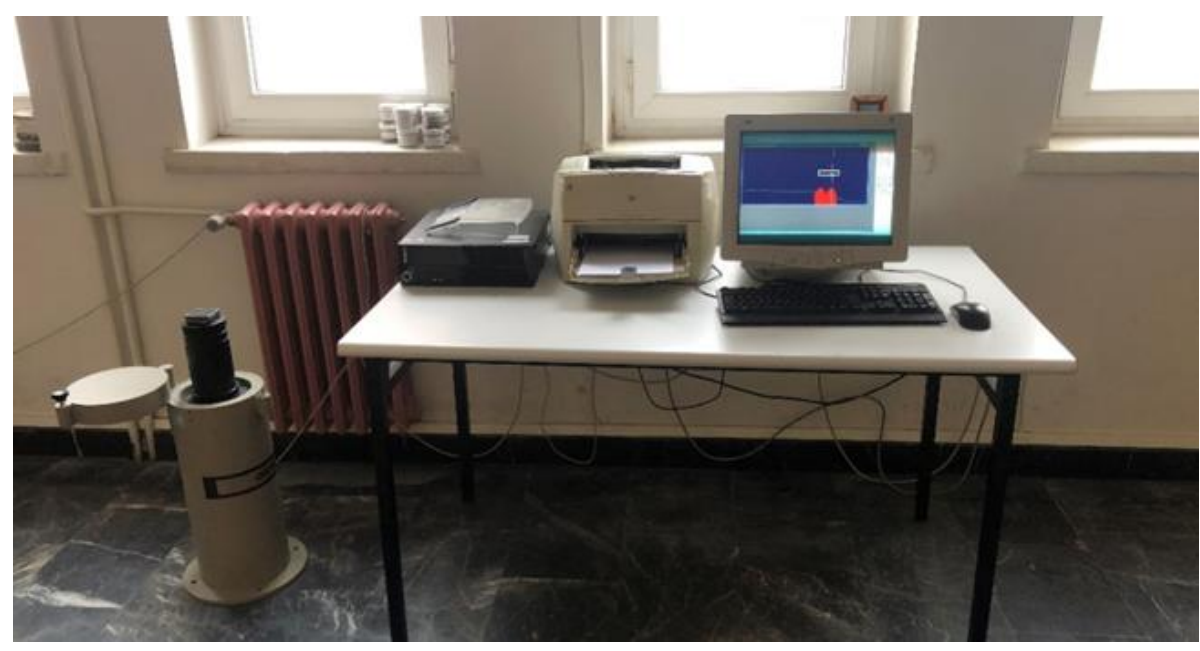

Şekil 1. Radyasyon zırhlaması deney düzeneği
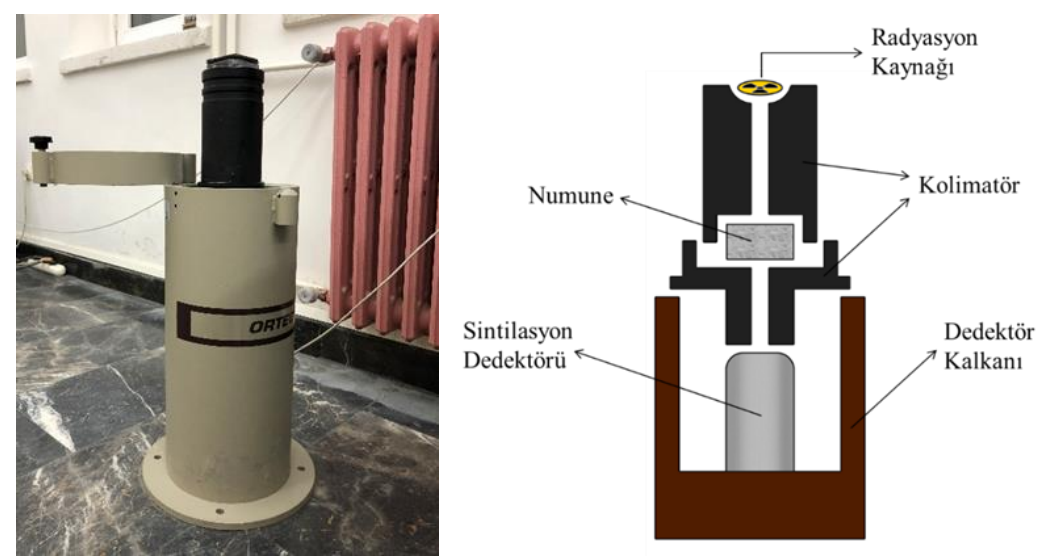

Şekil 2. Deneylerde kullanılan kaynak, numune ve dedektör düzeneği

Deney düzeneğinde radyoaktif ışınların huzmesinin çapını ve şeklini sınırlayan kolimatörler ile birlikte ORTEC marka NaI(TI) sodyum iyodür sintilasyon dedektörü kullanılmıştır. Radyoaktif kaynak olarak ${ }^{60} \mathrm{Co}$ ve ${ }^{152} \mathrm{Eu}$ kaynakları kullanılmıştır. ${ }^{60} \mathrm{Co}$ kaynağından 1,173 ve $1,333 \mathrm{MeV},{ }^{152} \mathrm{Eu}$ kaynağından ise $0,122,0,245,0,344,0,444$, $0,779,0,964,1,112$ ve $1,408 \mathrm{MeV}$ gama enerjileri için ölçümler gerçekleștirilmiștir. Deneye tabi tutulan polimer beton numunesi ve radyoaktif kaynaklar Şekil 3'te gösterilmiştir.
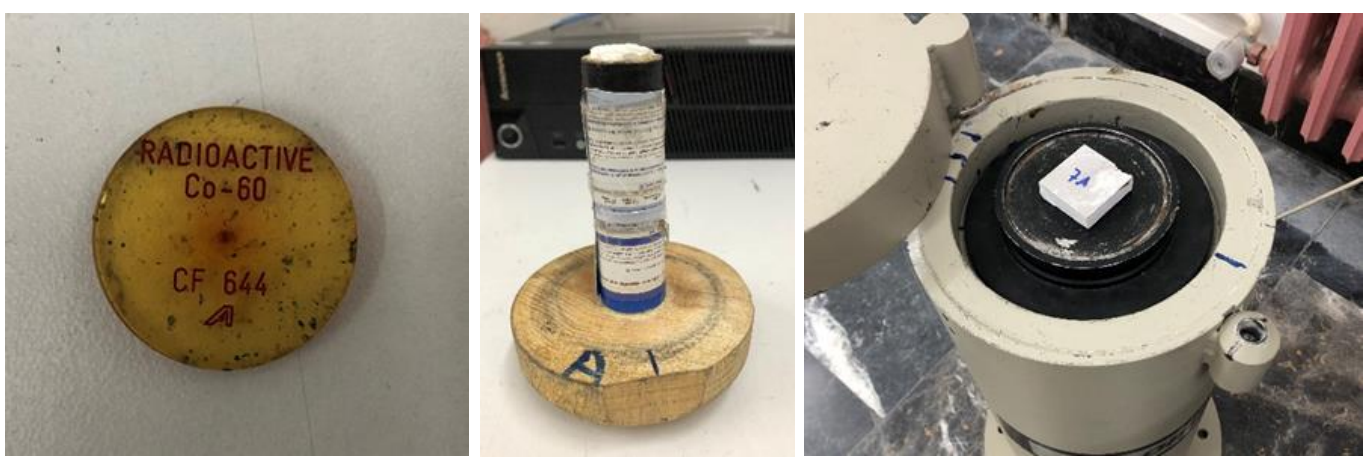

Şekil 3. Deneylerde kullanılan radyoaktif kaynaklar ve polimer beton numunesi

Deneysel ölçümlerdeki veriler dedektörün bağlı olduğu bilgisayardaki Scintivision 32 programı aracılığıyla spektrum olarak alınmıştır [2]. Radyoaktif kaynaklardan elde 
edilen gama enerjilerinin Scintivision 32 programında tanımlanabilmesi için tüm spektrumlarda pik noktaların enerjileri için kalibrasyon yapılmış ve spektrumlardaki pik alanları seçilmiştir. İlk olarak düzenek, içerisinde deney numunesi olmadan çalıştırılmış, pik alanları deneyde kullanılacak tüm numuneler için aynı gauss dağılım aralığında seçilmiş ve boş ölçüm yapılarak $\mathrm{I}_{0}$ değeri tüm malzemeler için aynı olarak belirlenmiştir. Daha sonra düzeneğe sırasıyla tüm deney numuneleri yerleştirilerek her pik alanlarındaki sayım sayıları ölçülmüş ve Beer-Lambert yasasına göre deneysel hesaplamalar gerçekleştirilmiştir [11].

Gelen radyasyonun şiddeti maddede aldığı yol boyunca azalmaktadır. Bir başka deyişle bir ışın demeti bir maddeden geçerken şiddeti azalmaktadır. Radyasyon şiddetindeki bu azalma matematiksel olarak Beer-Lambert yasası ile ifade edilmektedir. Beer-Lambert yasasına göre; radyasyonun zayıflatılması amaciyla önüne konulan bir engel; radyasyonun şiddetini, radyasyonun cinsinden bağımsız olacak şekilde üstel olarak zayıflatmaktadır (Şekil 4).

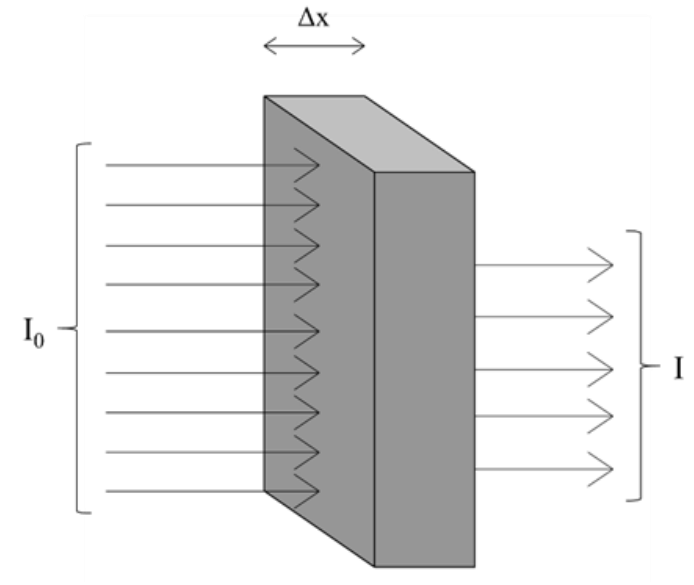

Şekil 4. Radyasyon şiddetinin malzeme tarafından zayıflatılması

$\mathrm{I}_{0}$ şiddetindeki 1şın demetinin $\Delta \mathrm{x}$ kalınlığındaki bir madde tabakasına nüfuz etmesi halinde bu maddeden geçen ışınlar Beer-Lambert yasasına göre üstel olarak soğurulacak ve maddeden geçen 1 şın demetinin yeni şiddeti I olacaktır. I değeri her zaman $\mathrm{I}_{0}$ değerinden küçük olmaktadır.

Atomik parçacığın ya da fotonun verilen bir zırh malzemesi ile etkileşime girme olasılığı lineer zayıflatma katsayısı $(\mu)$, olarak tanımlanmakta ve birimi $\mathrm{cm}^{-1}$ olarak ifade edilmektedir. Lineer zayıflatma katsayısı; fotoelektrik olay, Compton saçılımı ve çift oluşumu etkileşimlerinin toplamıdır. Radyasyonun cinsine, enerji seviyesine ve etkileşime girdiği maddenin içerik, kalınlık, yoğunluk gibi özelliklerine bağlıdır.

$\mathrm{Bu}$ verilerin 1şığında, lineer zayıflatma katsayısı aşağıdaki formülasyona göre bulunmaktadır [11].

$$
\mu=\frac{1}{\Delta x} \ln \frac{I_{0}}{I}
$$

Burada $\Delta \mathrm{x}$ zırh malzemesinin kalınlığı, $\mathrm{I}_{0}$ malzemeye gelen radyasyon enerjisi, I ise malzemeden geçen radyasyonun enerjisini göstermektedir. 
Fotonların soğurulmasında soğurucu ortamın kalınlığının yanı sıra yoğunluğu da önemli olmaktadır. Kütlesel zayıflatma katsayısı $\left(\mu_{\mathrm{m}}\right)$ ise lineer zayıflatma katsayısının malzeme yoğunluğuna bölünmesiyle elde edilir. Birimi $\mathrm{cm}^{2} / \mathrm{g}$ olarak ifade kütlesel zayıflatma katsayısı aşağıdaki şekilde elde edilmektedir [11].

$$
\mu_{m}=\frac{\mu}{\rho}
$$

Burada $\rho$, zırh malzemesinin yoğunluğunu göstermektedir.

Deneysel hesaplamaların yanı sıra verilerin karşılaştırılması için teorik hesaplamalar da gerçekleştirilmiştir. Teorik hesaplamalar web tabanlı XCOM programı kullanılarak yapılmıştır. XCOM programında herhangi bir element, bileşik veya karışım malzemelerinin $1 \mathrm{keV}$ 'den $100 \mathrm{GeV}$ 'e kadar olan enerji aralıklarındaki kütlesel zayıflatma katsayıları teorik olarak hesaplanabilmektedir.

XCOM bilgisayar programı aracılığı ile malzemelerin çeşitli enerjilerdeki radyasyon karşısındaki saçılma, fotoelektrik olay, çift oluşumu, tesir kesitleri ve buradan da toplam kütlesel zayıflatma katsayıları hesaplanmaktadır. Bu teorik hesaplama için programa her bir malzemenin kimyasal içeriklerinin ve ağırlıç̧a yüzdelerinin girilmesi gerekmektedir.

\section{Bulgular}

\subsection{Polimer betonların karışım oranları ve yoğunlukları}

Polimer betonların üretilebilirliği açısından reçine ve faz malzemeler için aynı standardın sağlanması amacıyla karışım oranları \%50'yi geçmeyecek şekilde birbirleri ile de orantılı olması açısından hacimce $\% 0, \% 15, \% 30$ ve $\% 45$ olarak belirlenmiştir.

Polimer beton numunelerinin tüm serileri için $\% 0, \% 15, \% 30$, ve $\% 45$ olarak belirlenen hacimce karışım oranları malzemelerin yoğunluklarındaki farklılıklar nedeniyle her karışım için ağırlıkça farklı oranlara karşılık gelmektedir. Üretilen tüm numunelerin yoğunlukları Tablo 3'te gösterilmiştir.

Tablo 3. Polimer beton numunelerinin yoğunlukları

\begin{tabular}{c|ccccccc}
\hline Numune & 100P & 15PE & 30PE & 45PE & 15PO & 30PO & 45PO \\
\hline $\begin{array}{c}\text { Yoğunluk } \\
\left(\mathbf{g} / \mathbf{c m}^{3}\right)\end{array}$ & 1,482 & 1,495 & 1,511 & 1,582 & 1,582 & 1,623 & 1,678 \\
\hline Açıklama & $\begin{array}{c}\% 0 \\
\text { Agrega }\end{array}$ & $\begin{array}{c}\% 15 \\
\text { Perlit }\end{array}$ & $\begin{array}{c}\% 30 \\
\text { Perlit }\end{array}$ & $\begin{array}{c}\% 45 \\
\text { Perlit }\end{array}$ & $\begin{array}{c}\% 15 \\
\text { Pomza }\end{array}$ & $\begin{array}{c}\% 30 \\
\text { Pomza }\end{array}$ & $\begin{array}{c}\% 45 \\
\text { Pomza }\end{array}$ \\
\hline
\end{tabular}

\subsection{Polimer betonların radyasyon zırhlaması deneyi sonuçları}

${ }^{60}$ Co kaynağının kullanıldığı deneysel ölçümlerde deney süresi, gerekli kalibrasyon işlemleri yapılarak $1000 \mathrm{sn}$ olarak seçilmiştir. ${ }^{152} \mathrm{Eu}$ kaynağında ise aynı deneysel ölçümler ${ }^{152} \mathrm{Eu}$ kaynağının radyoaktivitesinin ${ }^{60} \mathrm{Co}$ kaynağına göre daha yüksek olmasından dolayı 500 sn gibi bir deney süresinde gerçekleştirilebilmiştir. Her iki kaynak kullanılarak gerçekleştirilen tüm deneysel ölçümlerde Beer-Lambert yasasında kullanılacak olan $\mathrm{I}_{0}$ ve I değerleri elde edilmiş ve gerekli hesaplamalar yapılmıştır. 
Deneysel çalışmalardan elde edilen veriler ile karşılaştırılması için XCOM programı kullanılarak 0.001 MeV'den $100000 \mathrm{MeV}$ 'e kadar olan gama enerji aralıklarında her polimer beton serisi için teorik hesaplamalar da yapılmıştır.

Gerçekleştirilen deneysel ve teorik hesaplamalara göre, polimer betonların çeşitli enerjilerdeki gama radyasyonları için lineer zayıflatma ve kütlesel zayıflatma katsayıları elde edilmişstir.

Çalışmadaki tüm polimer beton numuneleri için belirtilen gama enerjilerinde deneysel olarak elde edilmiș kütlesel zayıflatma katsayıları ile XCOM programı kullanılarak teorik olarak elde edilen kütlesel zayıflatma katsayıları, Şekil 5-11 arasında karşılaştırmalı olarak gösterilmiştir.

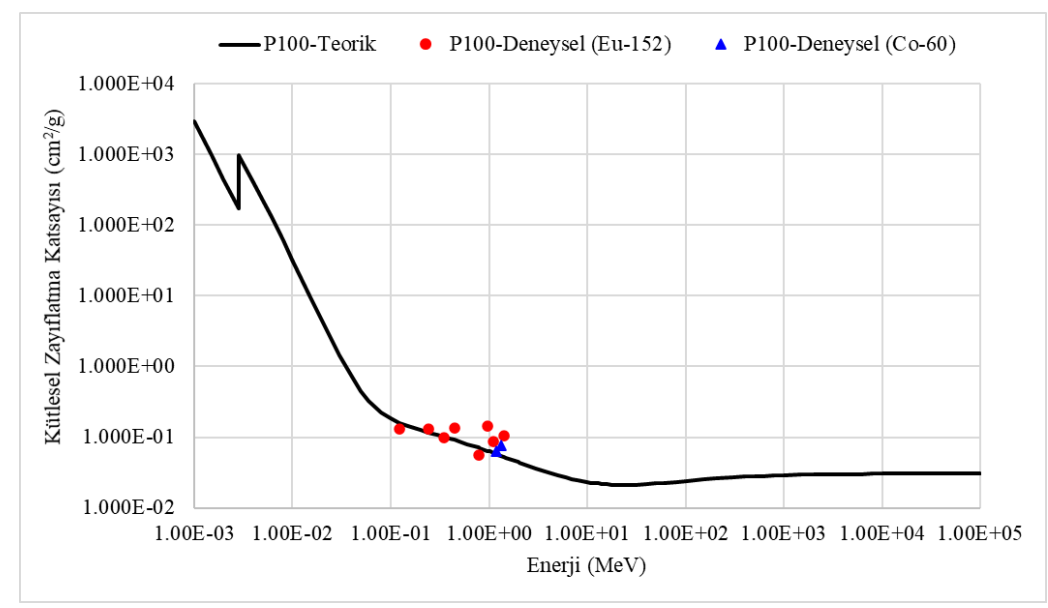

Şekil 5. Faz malzemesiz polyester reçineli polimer betonun kütlesel zayıflatma katsayısının deneysel ve teorik olarak gösterilmesi

Şekil 5'te görüldüğü gibi polyester reçine kullanılarak üretilen faz malzemesiz polimer betonda gama radyasyonu için kütlesel zayıflatma katsayılarının, teorik ve deneysel hesaplamalarda birbirleri ile uyum içerisinde olduğu görülmektedir. Bu uyum hem ${ }^{152} \mathrm{Eu}$ hem de ${ }^{60} \mathrm{Co}$ radyoaktif kaynaklarının tüm enerjilerinde geçerlidir.

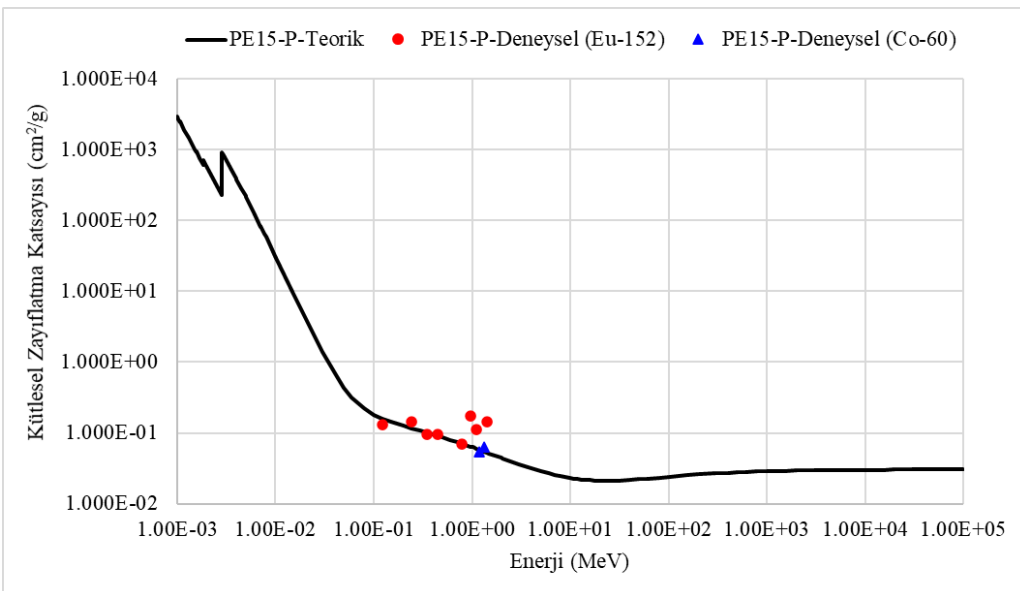

Şekil 6. \% 15 Perlit içeren polyester reçineli polimer betonların kütlesel zayıflatma katsayısının deneysel ve teorik olarak gösterilmesi 


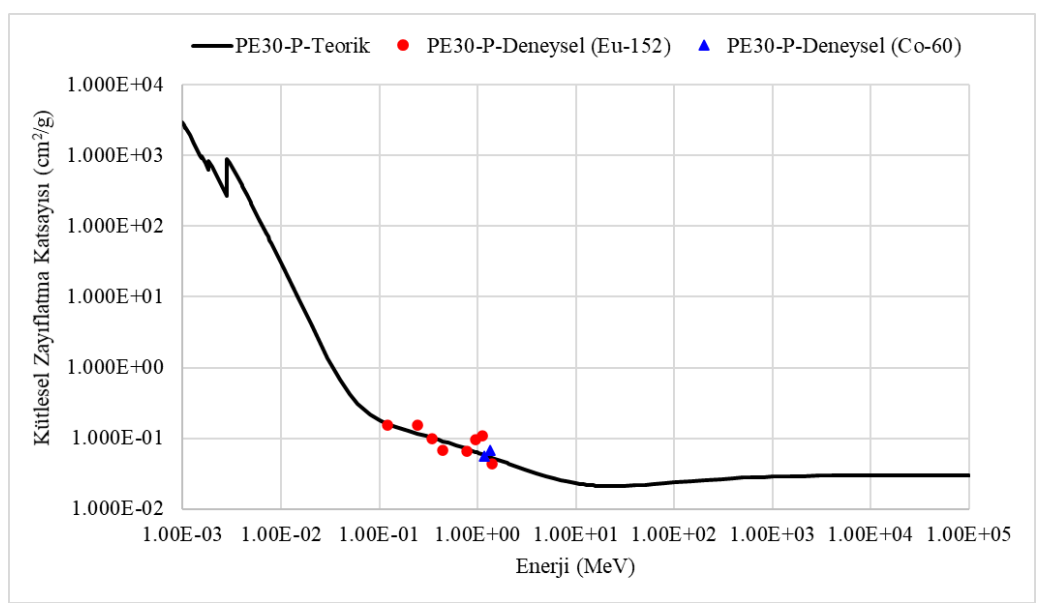

Şekil 7. \%30 Perlit içeren polyester reçineli polimer betonların kütlesel zayıflatma katsayısının deneysel ve teorik olarak gösterilmesi

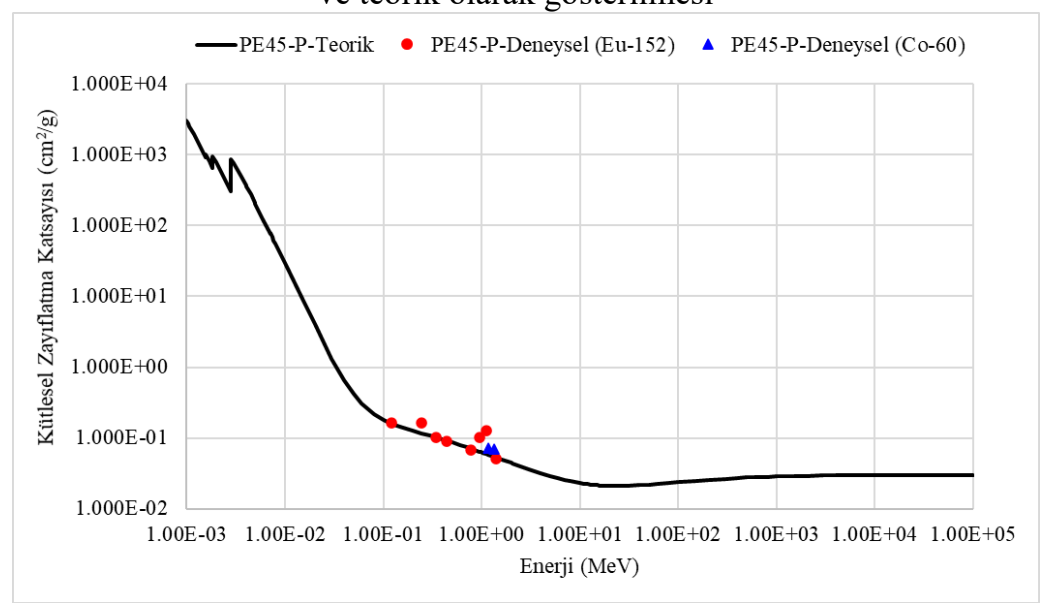

Şekil 8. \%45 Perlit içeren polyester reçineli polimer betonların kütlesel zayıflatma katsayısının deneysel ve teorik olarak gösterilmesi

Şekil 6-8'de görüldüğü gibi perlit içeren polimer betonlarda gama radyasyonu için kütlesel zayıflatma katsayılarının, teorik ve deneysel hesaplamalarda birbirleri ile uyum içerisinde olduğu görülmektedir. Bu uyum faz malzemesiz numunede olduğu gibi hem ${ }^{152} \mathrm{Eu}$ hem de ${ }^{60} \mathrm{Co}$ radyoaktif kaynaklarının tüm enerjileri için geçerlidir.

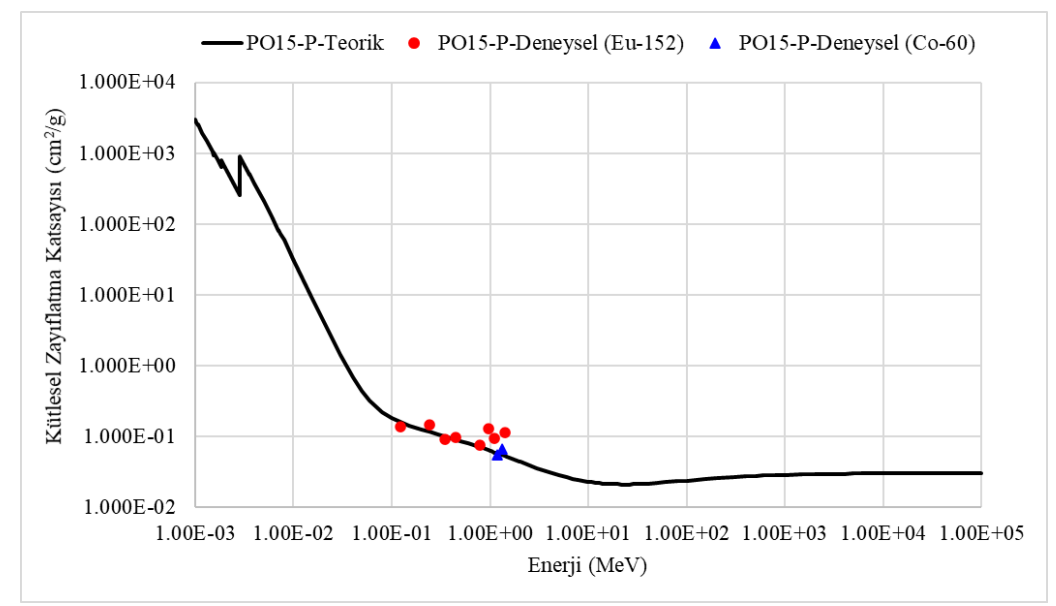

Şekil 9. \%15 Pomza içeren polyester reçineli polimer betonların kütlesel zayıflatma katsayısının deneysel ve teorik olarak gösterilmesi 


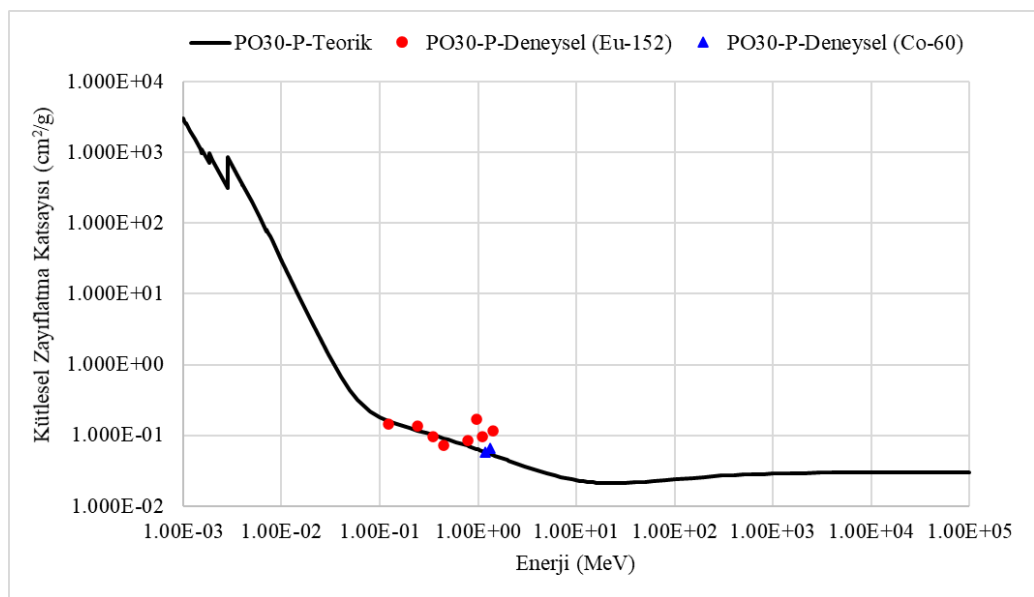

Şekil 10. \%30 Pomza içeren polyester reçineli polimer betonların kütlesel zayıflatma katsayısının deneysel ve teorik olarak gösterilmesi

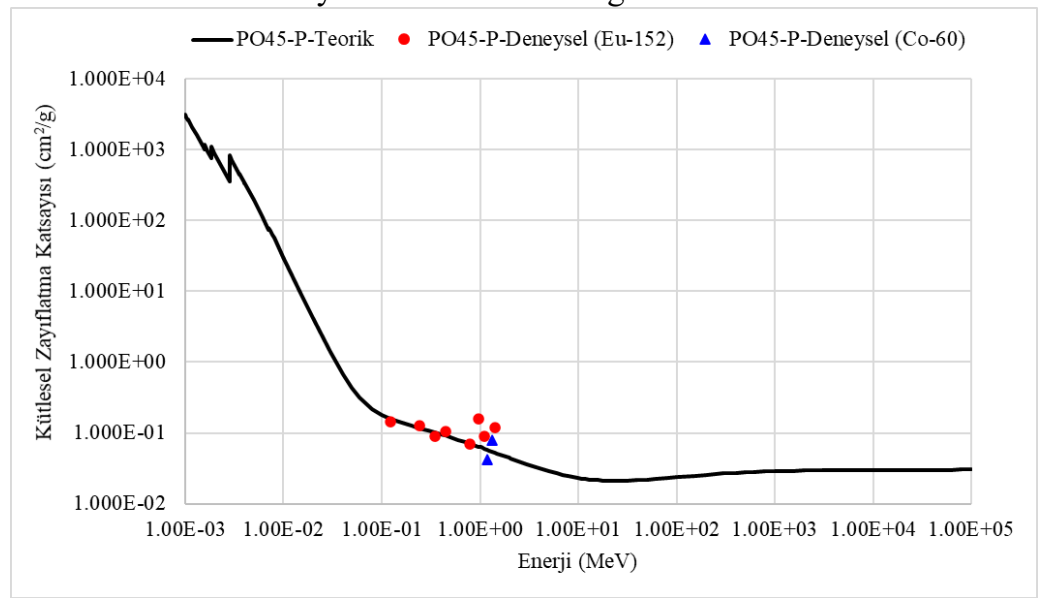

Şekil 11. \%45 Pomza içeren polyester reçineli polimer betonların kütlesel zayıflatma katsayısının deneysel ve teorik olarak gösterilmesi

Şekil 9-11'de görüldüğü gibi pomza içeren polimer betonlarda gama radyasyonu için kütlesel zayıflatma katsayılarının, teorik ve deneysel hesaplamalarda birbirleri ile uyum içerisinde olduğu görülmektedir. Bu uyum perlit içeren numunelerde de olduğu gibi radyoaktif kaynakların tüm enerjileri için geçerlidir.

Kütlesel zayıflatma katsayılarının teorik ve deneysel sonuçları her ne kadar birbirleri ile uyumlu olsa da düşük enerjilerde yüksek enerjilere göre daha anlamlı sonuçlar elde edilmiştir. Özellikle yoğunluğu birbirine yakın olan numunelerde ve birbirine çok yakın olan enerjilerde kütlesel zayıflatma katsayısının sayısal değerleri de birbirlerine çok yakın bulunmuştur. $\mathrm{Bu}$ da literatürce de bilindiği üzere malzeme yoğunluğunun ve radyasyon şiddetinin radyasyon zırhlaması üzerine etkilerinin bir sonucudur [14].

Ayrıca üretilen tüm polimer beton numunelerinin, yoğunlukları ile radyasyon zırhlama deneyi sonrası elde edilen lineer zayıflatma katsayıları arasındaki ilişkiler Şekil 12'de gösterilmiştir. 


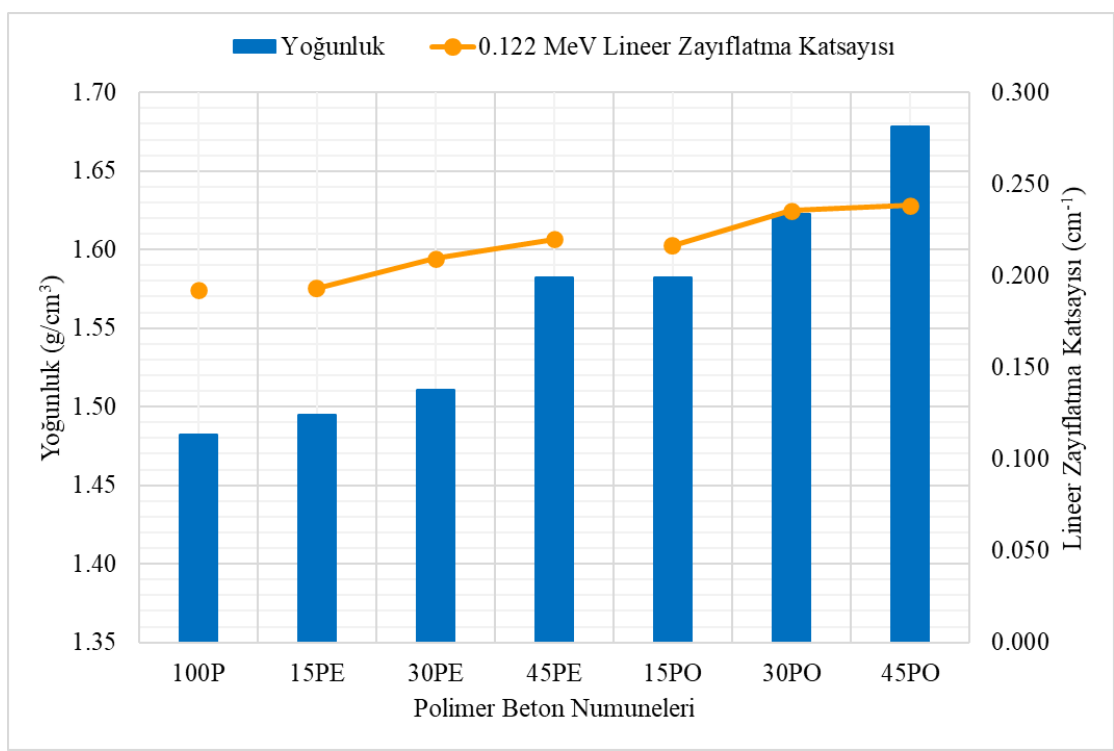

Şekil 12. Polimer betonların yoğunluk lineer zayıflatma katsayısı ilişkisi

Şekil 12 'de görüldüğü gibi tüm polimer beton numuneleri yoğunlukları ve radyasyon zırhlama deneyi sonuçları incelendiğinde yoğunluklar ile lineer zayıflatma katsayıları arasında doğrudan bir ilişki olduğu görülmektedir. Bu ilişkiyi ortaya çıkarmak için $0,122 \mathrm{MeV}$ enerjisindeki sonuçlar grafiğe aktarılmıştır. $0,122 \mathrm{MeV}$ enerjisinin seçilmesindeki temel sebep bu enerjinin deneysel çalışmadaki en düşük gama enerjisi olmasından dolayı deney sonuçlarını yorumlamada daha anlaşılır olmasıdır.

Genel olarak polimer betonlarda yoğunluğun artmasıyla lineer zayıflatma katsayıları da artmıştır. Yani yoğunluğu yüksek olan numunelerin lineer zayıflatma katsayıları yüksek, yoğunluğu düşük olan numunelerin ise lineer zayıflatma katsayılarının düşük olduğu görülmektedir.

Ayrıca faz malzeme miktarının \%15 - \%30 - \%45 artışına bağlı olarak yoğunluğun artmasıyla hem perlit hem pomzalı serilerde lineer zayıflatma katsayılarında artış görülmektedir. Bu durum agrega artışına bağlı olarak malzemelerin yoğunluklarının arttığının bir göstergesidir.

\section{Sonuç ve Yorum}

$\mathrm{Bu}$ çalışma kapsamında, polyester reçine ile çeşitli oranlarda perlit ve pomza agregalarının karıştırılmasıyla üretilen polimer betonların radyasyon zırhlama performansları deneysel ve teorik olarak araştırılmıştır. Yapılan araştırmalar neticesinde elde edilen sonuçlar aşağıda maddeler halinde sunulmuştur.

- Tüm polimer betonlarda, gama radyasyonu için kütlesel zayıflatma katsayılarının hem teorik hem de deneysel hesaplamalarda birbirleri ile uyum içerisinde olduğu ortaya çıkmıştır.

- Perlit ve pomza içeren polimer betonlar kendi içlerinde karşılaştırıldıklarında yoğunluğu fazla olan pomza içeren beton numunelerinin perlit içeren betonlara göre radyasyon zırhlaması açısından daha elverişli olduğu ortaya çıkmıştır. 
- Elde edilen radyasyon zayıflatma katsayıları incelendiğinde yoğunluğu daha yüksek agregalar ile üretilecek olan betonların radyasyon zırhlaması açısından daha uygun olacağı önerilmektedir.

- Yoğunluğu birbirine yakın olan polimer beton numunelerinde ve birbirine çok yakın olan gama enerjilerinde kütlesel zayıflatma katsayıları birbirlerine yakın değerlerde bulunmuştur. Bu da malzeme yoğunluğunun ve radyasyon şiddetinin radyasyon zırhlaması üzerine etkilerinin bir sonucu olarak ortaya çıkmıştır.

- Üretilen polimer betonların yoğunlukları dikkate alındığında kütlesel zayıflatma katsayılarının düşük enerjilerdeki ölçümlerinde yüksek enerjilere göre daha anlamlı sonuçlar elde edilmiştir.

- Agrega oranlarının \%15 - \%30 - \%45 artışına bağlı olarak polimer betonların lineer zayıflatma katsayılarında artış görülmektedir. Bu durum agrega artışına bağlı olarak malzemelerin yoğunluklarının arttığının bir göstergesi olarak ortaya çıkmıştır.

\section{Araştırmacıların Katkı Oranı Beyanı}

Ali Nadi KAPLAN: Araștırma, Kaynak/Materyal/Malzeme Temini, Orijinal Taslak Yazımı. Cengiz ÖZEL: Denetim/Gözlem/Tavsiye, İnceleme ve Düzenleme, Veri İyileştirme.

\section{Destek ve Teşekkür Beyanı}

Bu çalışma Ali Nadi KAPLAN'ın doktora tezinden türetilmiştir. Yazarlar olarak radyasyon zırhlama deneylerini gerçekleştirmemizi sağlayan Ondokuz Mayıs Üniversitesi öğretim üyesi Prof. Dr. Hasan GÜMÜŞ hocamıza teşekkür ederiz.

\section{Çatışma Beyanı}

$\mathrm{Bu}$ çalışmanın yazarları olarak herhangi bir çatışma beyanımız bulunmadığını bildiririz

\section{Etik Kurul Onayı ve/veya Aydınlatılmış Onam Bilgileri}

$\mathrm{Bu}$ çalışmanın yazarları olarak herhangi bir etik kurul onayı ve/veya aydınlatılmış onam bilgileri beyanımız bulunmadı ̆̆ını bildiririz.

\section{Kaynakça}

[1] Ş. Kılınçarslan, "Barit agregalı ağır betonların radyasyon zırhlamasındaki özellikleri ve optimal karışımlarının araştırılması,” Doktora Tezi, Fen Bilimleri Enstitüsü, Süleyman Demirel Üniversitesi, Isparta, 2004.

[2] A. Küçükkılınç, "Samsun ilindeki bazı yapı malzemelerinin gama soğurma özelliklerinin incelenmesi," Yüksek Lisans Tezi, Fen Bilimleri Enstitüsü, Ondokuz Mayıs Üniversitesi, Samsun, 2019.

[3] Z. M. Doğan, "Limonit ve siderit agregalarının ağır beton üretiminde kullanılabilirliğinin araştırılması,” Yüksek Lisans Tezi, Fen Bilimleri Enstitüsü, Fırat Üniversitesi, Elazı̆̆g, 2012.

[4] B. Akyol, "Radyoterapi merkezi inşaatlarında malzeme seçiminin tasarıma etkisinin araştırılması," Yüksek Lisans Tezi, Fen Bilimleri Enstitüsü, Süleyman Demirel Üniversitesi, Isparta, 2015.

[5] A. Akkaş, "Alüminyum-Bor-Karbür kompozit malzemelerin radyasyon karşısındaki davranışının belirlenmesi, XCOM bilgisayar programı ile incelenmesi ve yeni bir hibrit kompozit radyasyon zırh malzemesi önerisi,” Doktora Tezi, Enerji Enstitüsü, İstanbul Teknik Üniversitesi, İstanbul, 2015. 
[6] S. Özen, "Denge ağırlığı ve radyasyonlu ortamlarda zırh işlevi amacına yönelik ağır beton tasarımı," Yüksek Lisans Tezi, Fen Bilimleri Enstitüsü, Uludağ Üniversitesi, Bursa, 2013.

[7] H. Ertaş, "Kurşun madeni atıklarının radyasyon zırhlama etkilerinin araştırılması," Yüksek Lisans Tezi, Fen Bilimleri Enstitüsü, Gümüşhane Üniversitesi, Gümüşhane, 2014.

[8] E. Bakırhan, "Kurşun maden atığı katkılı ağır betonların radyasyon soğurma katsayılarınınewqrfdcvf 662-1460 keV enerji aralığında incelenmesi," Yüksek Lisans Tezi, Fen Bilimleri Enstitüsü, Gümüşhane Üniversitesi, Gümüşhane, 2017.

[9] Ş. Kılınçarslan ve A. Seven, "Baritli hazır sıva kaplamalarının radyasyon zırh malzemesi olarak kullanımının araştırılması," Süleyman Demirel Üniversitesi Fen Bilimleri Enstitüsü Dergisi, 18(3), 914,2014

[10] Ş. Biber Temircik, "Yapı Malzemelerinin Radyasyon Geçirgenliği ve Mühendislik Özelliklerinin Araştırılması,” Doktora Tezi, Fen Bilimleri Enstitüsü, Kahramanmaraş Sütçü İmam Üniversitesi, Kahramanmaraş, 2015.

[11] A. Sharma, M. I. Sayyed, O. Agar, M. R. Kaçal, H. Polat, and F. Akman, "Photon-shielding performance of bismuth oxychloride-filled polyester concretes," Mater. Chem. Phys., 241, 1-9, 2020.

[12] O. Gencel, W. Brostow, C. Ozel, and M. Filiz, "Concretes containing hematite for use as shielding barriers," Mater. Sci., 16 (3), 1392-1320, 2010.

[13] İ. B. Topçu ve A. Uğurlu, "Barit ile üretilmiş ağır betonlar üzerine bir çalışma," Türkiye Mühendislik Haberleri (TMH), 474 (4), 51-57, 2012.

[14] I. M. Nikbin, R. Mohebbi, S. Dezhampanah, S. Mehdipour, R. Mohammadi, and B. Nejat, "Gamma ray shielding properties of heavy-weight concrete containing nano-TiO ${ }_{2}$," Radiat. Phys. Chem., 162, 157-167, 2019.

[15] Ç. Akkaya Özden, "Polimer betonların donma - çözülme etkisine dayanıklılığı," Yüksek Lisans Tezi, Fen Bilimleri Enstitüsü, Namık Kemal Üniversitesi, Tekirdağ, 2010.

[16] A. Douba, M. Genedy, E. N. Matteo, U. F. Kandil, J. Stormont, and M. M. Reda Taha, "The significance of nanoparticles on bond strength of polymer concrete to steel," Int. J. Adhes. Adhes., 74, 77-85, 2017.

[17] T. Özturan, “Özel betonlar,” Hazır Beton Dergisi, 118, 70-82, 2013.

[18] O. Soykan, C. Öcal, C. Özel, A. Eren ve O. Çelik, "Deprem sonrası betonarme elemanların polimer beton ile onarım ve güçlendirilmesi," Uluslararası Burdur Deprem ve Çevre Sempozyumu (IBEES2015), Burdur, 2015, s. 227-232.

[19] TS EN 12390-7, "Beton - Sertleşmiş Beton Deneyleri - Bölüm 7: Sertleşmiş Betonun Yoğunluğunun Tayini," Türk Standartları Enstitüsü (TSE), 14 s., Ankara, 2019.

[20] M. J. Berger, J. H. Hubbell, S. M. Seltzer, J. Chang, J. S. Coursey, R. Sukumar, D. S. Zucker, and K. Olsen, "XCOM: Photon cross section database," National Institute of Standards and Technology (NIST), Gaithersburg, USA, 2010. 